\title{
Extraction of Plasma Insulin in Radioimmunoassay for Removal of Nonspecific Inhibitor and of Circulating Insulin Antibody
}

\author{
Akira Ohneda, Takayoshi Toyota, \\ Shinichiro Sato and Shoichi Yamagata \\ The Medical Department (Prof. S. Yamagata), \\ Tohoku University School of Medicine, Sendai
}

\begin{abstract}
In the two-antibody assay system for insulin, insulin-free human plasma and human globulin fraction reduced the percentage of precipitated insulin-131. Insulin antibody in plasma was partially absorbed by means of anti-human globulin rabbit serum, which was not available for the removal of endogenous insulin antibody. In order to remove the inhibiting factor as well as the circulating insulin antibody, a simple method for the extraction of plasma insulin was described. The method consists of extraction by acid-ethanol and precipitation in cold acetone. The recovery rate of insulin- ${ }^{131} \mathrm{I}$ added to serum by the present method was $92 \%$, and that of human insulin added to a pooled human plasma was in the range of 80 to $94 \%$. The extract contained a small amount of albumin but not globulin. The extraction method completely separated the insulin from the insulin-antibody complex.

The mean values of the fasting extractable insulin in human plasma were 20.5, $19.3,22.6$ and $10.0 \mu \mathrm{U}$ per $\mathrm{ml}$ in normal subjects, mild, moderate and severe diabetic patients, respectively. In the latter group the insulin response to glucose load decreased. Extractable insulin in plasma of several diabetic patients with insulin antibody was found to be 10 to $32 \mu \mathrm{U}$ per $\mathrm{ml}$. The insulin level in plasma of insulin-dependent patient with antibody to insulin could be estimated by the present extraction method.
\end{abstract}

Since Yalow and Berson ${ }^{1}$ introduced the radioimmunoassay of insulin, various modified methods of the assay have been devised by previous authors. ${ }^{2-6}$ The methods vary in the way of separating free labeled insulin from labeled insulin bound with insulin antibody. In the two-antibody system which was first reported by Morgan and Lazarow, ${ }^{3}$ free labeled insulin is separated by means of precipitation with the second antibody to guinea pig serum from bound labeled insulin. This method has been widely used throughout the world because of several advantages in carrying out the insulin assay. In this system, however, as Morgan and Lazarow ${ }^{7}$ and Hales and Randle ${ }^{8}$ reported, rat serum as well as human plasma inhibits the second reaction of anti-guinea pig serum with anti-insulin guinea pig serum. It was reported by Morgan et al. ${ }^{9}$ that the addition of ethylendiaminetetraacetate (EDTA) at the second reaction of the two-antibody

Received for publication, September 2, 1969. 
system eliminates the inhibition by rat serum. Reduction in inhibition of the second reaction by means of a large amount of heparin was also shown by Soeldner and Slone ${ }^{10}$ and Welborn and Fraser. ${ }^{11}$

The production of endogenous antibody to exogenous insulin was observed in almost all diabetic patients administered insulin, ${ }^{12}$ endogenous antibody to insulin being proved in $80 \%$ of diabetic patients injected with insulin in our own series. ${ }^{13}$ Since the endogenous insulin antibody would interfere with any method of radioimmunoassay of insulin, it is necessary to remove the endogenous insulin antibody prior to the radioimmunoassay for insulin in plasma of diabetic patients who have been injected with insulin and have shown to have insulin antibody.

The purpose of this report is to describe the approach for the assay of circulation insulin in human plasma in order to eliminate the inhibition at the second reaction in the two-antibody system and to remove the endogenous antibody to insulin.

\section{Materials and Methods}

Beef crystalline insulin and human insulin were donated by Eli Lilly and Company. Insulin. ${ }^{-131} \mathrm{I}$ was purchased from Abbott Laboratories, its specific radioactivity being 4-7 me per mg of insulin. Antiserum to insulin was obtained from guinea pigs injected on several occasions subcutaneously with $1 \mathrm{mg}$ of beef insulin mixed with Freund's complete adjuvant (Difco Lab.) at four-week intervals. Anti-guinea pig sera were obtained from rabbits injected several times with a mixture of guinea pig serum and Freund's complete adjuvant. Normal rabbit sera were obtained from rabbits and the sera diluted one to one hundred were used in the assay. Bovine albumin fraction $\mathrm{V}$ was purchased from Sigma and Co.

Insulin assay was carried out principally by the method of Morgan and Lazarow with some modifications described later.

Insulin-free plasma was prepared by the addition of ammonium hydroxide for 24 hours and adjusting $\mathrm{pH}$ to 7.4 with concentrated hydrochloric acid, according to the method of Grodsky and Forsham. ${ }^{2}$ Human globulin was prepared from pooled serum using saturated ammonium sulfate (Ishida et al. ${ }^{14}$ ).

Insulin antibody was measured by paper chromatography according to Berson et al.12 A mixture of $0.2 \mathrm{ml}$ of human plasma and $0.2 \mathrm{ml}$ of insulin-131 $(80 \mathrm{~m} \mu \mathrm{g})$ was incubated at $4^{\circ} \mathrm{C}$ for 24 hours and stripped on filter paper. Paper chromatography was carried out by hydrodynamic flow. After staining for protein fraction by brom phenol blue, strips were dried in the oven. Radioactivity was counted by radio-paper-chromatogram scanner (Aloka, JPC 102). Insulin binding capacity of antibody was calculated by the following formula:

$$
\text { Antibody index }=\frac{\mathrm{B}}{\mathrm{B}+\overline{\mathrm{F}}} \times 100(\%)
$$

B: radioactivity bound with protein fraction

$F$ : radioactivity at the origin

Anti-human globulin rabbit sera were produced in rabbits by the injection of human globulin mixed with Freund's complete adjuvant.

In order to extract insulin from plasma, Scott and Fisher's method ${ }^{15}$ for the extraction of insulin from the pancreas was modified as follows: A mixture of $2 \mathrm{ml}$ of plasma and $8 \mathrm{ml}$ of acid ethanol was incubated at $4^{\circ} \mathrm{C}$ for one hour and was centrifuged for 20 minutes at $10,000 \mathrm{rpm}$. After centrifugation the supernatant was removed and the precipitate was extracted again with $8 \mathrm{ml}$ of acid alcohol. The two supernatants were combined and were poured into 15 volumes of cold acetone. The supernatant was discarded and the precipi- 
tate was dried in vacuum and stored at room temperature. Prior to immunoassay for insulin the precipitate was ground to powder and resuspended in $2 \mathrm{ml}$ of distilled water and incubated at $4^{\circ} \mathrm{C}$ for one hour to ensure solubilization. Then $\mathrm{pH}$ of the solution was adjusted to 7.4 with normal sodium hydroxide.

Human blood was obtained in a syringe rinsed with concentrated heparin by venipuncture. Blood for glucose determination was obtained from the ear lobe and blood sugar was measured by the ferricyanide method of Fujita and Iwatrke, ${ }^{16}$ which showed almost the same level as Hagedorn-Jensen's method. ${ }^{17}$

\section{Results}

(a) Insulin assay. To a mixture of $0.5 \mathrm{ml}$ of human standard insulin or sample and $0.5 \mathrm{ml}$ of borate buffer of varied $\mathrm{pH}$ containing $1 \%$ bovine serum albumin were added $0.2 \mathrm{ml}$ of insulin- ${ }^{131} \mathrm{I}(10 \mu \mathrm{U})$ and $0.2 \mathrm{ml}$ of anti-insulin guinea pig serum (1:20,000 dilution) and the mixture was incubated at $4^{\circ} \mathrm{C}$ up to 4 days (first incubation) (cf. ref. 3). Then $0.2 \mathrm{ml}$ of diluted normal guinea pig serum and $0.2 \mathrm{ml}$ of anti-guinea pig serum rabbit serum were added to the reaction mixture and the mixture was further incubated at $4^{\circ} \mathrm{C}$ up to 48 hours (second incubation). Free insulin-131 I was removed by centrifugation at 5,000 rpm for 10 minutes and the precipitate was washed with borate buffer and the centrifugation was repeated. From radioactivities of supernatant and precipitate, per cent of precipitated insulin-131I was calculated. Per cent of precipitated insulin- ${ }^{131} \mathrm{I}$ was increased 24 hours after the start of the first incubation and reached a plateau at about 48 hours of incubation. Per cent of precipitated insulin-131 I reached the maximum at 24 hours of the second incubation. To determine the influence of $\mathrm{pH}$ of the assay system upon the per cent of precipitated insulin-131 I, the assay mixture was incubatd at various $\mathrm{pH}$. The maximum precipitation was obtained at $\mathrm{pH} 7.0$ to 8.0.

From these results, the following assay system was adopted: the assay mixture adjusted to $\mathrm{pH} 7.4$ was incubated for 48 hours in the first incubation and for 24 hours in the second incubation.

TABle 1. Mean percentage of precipitated insulin-131I for various samples in the first incubation mixture

\begin{tabular}{l|c}
\hline \multicolumn{1}{c|}{ Samples } & Precipitated insulin.131 I \%) \\
\hline Borate buffer & 79.7 \\
Insulin-free human serum & 24.1 \\
Extracted insulin-free human serum & 78.2 \\
Human serum globulin & 47.7 \\
Diluted human serum globulin (1 to 16) & 66.5
\end{tabular}

(b) Influence of human globulin upon percentage of precipitated labeled insulin. When $0.5 \mathrm{ml}$ of insulin-free human serum was employed instead of borate buffer in the first incubation, $25 \%$ of labeled insulin was precipitated, whereas the value obtained with borate buffer was $80 \%$. The extract of the insulin-free human 
A. Ohneda et al.

serum incubated in the first reaction yielded precipitation of $80 \%$ of insulin-131. When $0.5 \mathrm{ml}$ of human globulin $(2.9 \mathrm{~g} / 100 \mathrm{ml})$ was incubated in the first incubation mixture, $47.7 \%$ of labeled insulin was precipitated. Even with $0.5 \mathrm{ml}$ of 16 times diluted human globulin $66 \%$ of labeled insulin were precipitated and this amount was equivalent to $15 \mu \mathrm{U}$ per $\mathrm{ml}$ of human insulin. These results are presented in Table 1. These results indicate that untreated human plasma or human globulin interfered nonspecifically with the immunological reaction. Other experiments in our laboratory have shown that human globulin does not give any influence upon the maximal binding of ${ }^{131} \mathrm{I}$-insulin in a single antibody system using paper chromatography. Therefore, the interference by plasma might occur at the step of the second incubation. Furthermore, the removal of globulin fraction from insulin-free serum reduced the inhibition and the maximal percentage of precipitated labeled insulin was restored.

(c) Removal of endogenous insulin antibody by means of anti-human globulin serum. To examine the possibility of absorbing the endogenous insulin antibody by the anti-human globulin, $0.3 \mathrm{ml}$ of human plasma with insulin antibody was incubated with $0.3 \mathrm{ml}$ of anti-human globulin rabbit serum at $4^{\circ} \mathrm{C}$ for 3 hours. After separation of the precipitate by centrifugation, the supernatant was incubated with labeled insulin. Then a paperchromatography was carried out on Toyo filter paper No. 51 (Toyo Filter Paper Co. Tokyo) and the insulin antibody index was calculated. Insulin antibody indices of sera $\$ 206$ and $\$ 220$ were 56.0 and $39.4 \%$, respectively, whereas the values were reduced to 19.1 and $20.5 \%$, respectively, when the anti-human globulin rabbit serum was added. These results showed the possibility of removing the endogenous insulin antibody in human plasma by antihuman globulin rabbit serum, although the absorption did not appear to be complete.

(d) Extraction of plasma by the modification of Scott and Fisher's method. Recovery of added insulin during extraction was determined using insulin-131I. Scott and Fisher's method, ${ }^{15}$ Mineshita's method ${ }^{18}$ (acid ethanol extraction and salting out) and the modification of Scott and Fisher's method were compared, and the mean and standard error of recovery for each extraction method was found to be $35.1 \pm 0.8$, $28.7 \pm 2.6$ and $91.8 \pm 1.6$, respectively. The recovery rate of human insulin added to insulin-free serum was found to be $80 \%$ by means of the modification of Scott

TABLE 2. Recovery rate of human insulin added to human plasma

\begin{tabular}{c|c|c|c}
\hline $\begin{array}{c}\text { Amount of human insulin } \\
\text { added to } 1 \mathrm{ml} \text { of plasma }(\mu \mathrm{U})\end{array}$ & $\begin{array}{c}\text { No. of } \\
\text { samples }\end{array}$ & $\begin{array}{c}\text { Insulin measured } \\
(\mu \mathrm{U} / \mathrm{ml})^{*}\end{array}$ & $\begin{array}{c}\text { Recovery rate } \\
(\%)\end{array}$ \\
\hline 0 & $\cdots 4$ & $33.2(1.9)$ & \\
25 & 4 & $48.3(1.8)$ & 83.0 \\
50 & 4 & $66.8(1.7)$ & 80.3 \\
100 & 4 & $125.3(8.6)$ & 94.1 \\
* Numbers in parentheses represent the standard errors.
\end{tabular}




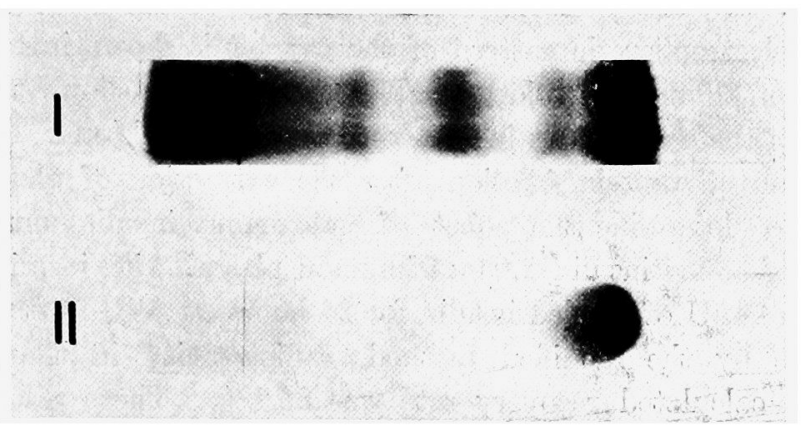

Fig. 1. Electrophoretogram of extracted plasma. I and II, untreated plasma and extracted plasma by the modification of Jephcott's method, respectively. Only albumin fraction can be seen in II.

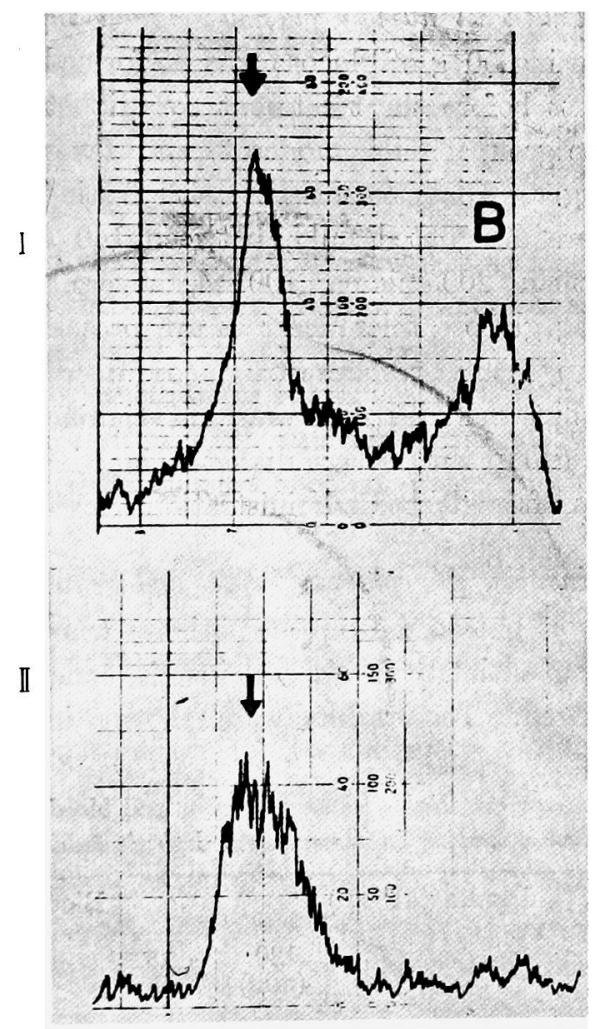

Fig. 2. Radio-paper chromatograms of insulin. ${ }^{-11} \mathrm{I}$ incubated with native (I) or extracted (II) human plasma. Arrows show the starting point and $\mathbf{B}$ represents the radioactivity bound with insulin antibody.

and Fisher's method. The recovery of human insulin added to a pooled human serum by the modified Scott's method ranged from 80 to $94 \%$, as shown in Table 2 . Therefore, this modification was adopted for the extraction of insulin in human 
plasma. The electrophoretic pattern of the extract is shown in Fig. 1, in which a small amount of albumin fraction can be seen. Fig. 2 shows the effect of the extraction upon the endogenous insulin antibody in the plasma. No radioactivity was observed in the protein fraction after the extraction of plasma but only at the origin. To determine the effect of endogenous insulin antibody upon the recovery rate of added insulin, $2.0 \mathrm{ml}$ of human plasma with insulin antibody were incubated with $44 \mu \mathrm{U}$ of labeled insulin for 24 hours at $4^{\circ} \mathrm{C}$. After the extraction of the mixture by the modified method, radioactivity in the precipitate was counted. The calculated recovery rate was $86.1 \%$. These results showed that almost all the labeled insulin bound to the insulin antibody was extracted and that the presence of endogenous antibody to insulin in human plasma did not affect the recovery of labeled insulin added to human plasma.

(e) Extractable insulin in human plasma without insulin antibody. The oral glucose tolerance test using $50 \mathrm{~g}$ of glucose was performed in 14 healthy subjects and 36 diabetic patients before the treatment for diabetes mellitus. The latter were divided into three groups: mild, moderate and severe diabetes, according to their fasting blood sugar. Diabetic patients with fasting blood sugar less than $140 \mathrm{mg}$ per $100 \mathrm{ml}$ were designated mild, between 140 and $200 \mathrm{mg}$ per $100 \mathrm{ml}$, moderate, and more than $200 \mathrm{mg}$ per $100 \mathrm{ml}$, severe. Blood sugar level and extracted insulin during glucose tolerance test are presented in Table 3 . In the moderate diabetic group, insulin response to glucose decreased 30 and 60 minutes after glucose loading but the difference was not significant compared with the normal group. In the group with severe diabetes, insulin concentration at fasting and 30 and 60 minutes after glucose administration decreased significantly.

(f) Extractable insulin in plasma with endogenous insulin antibody. In another series, blood was obtained from the patients who had been injected with insulin. Insulin binding antibody index and insulin concentration in the extract of plasma were measured. The results were shown in Table 4. Extractable

TABLE 3. Mean extractable plasma insulin and blood sugar during glucose loading in normal and diabetic subjects

\begin{tabular}{c|c|c|c|c|c|c|c|c|c|c}
\hline & $\begin{array}{c}\text { Nunber } \\
\text { of } \\
\text { Groups }\end{array}$ & \multicolumn{4}{|c|}{ Insulin $(\mu \mathrm{U} / \mathrm{ml})$} & \multicolumn{4}{c}{ Blood sugar $(\mathrm{mg} / 100 \mathrm{ml})$} \\
& subjects & Fasting & 30 & 60 & $\begin{array}{c}120 \\
(\mathrm{~min})\end{array}$ & Fasting & 30 & 60 & 90 & $\begin{array}{c}120 \\
(\mathrm{~min})\end{array}$ \\
\hline Normal & 14 & 20.5 & 37.8 & 32.1 & 24.2 & 92.7 & 154.6 & 136.8 & 125.0 & 96.2 \\
& & $(3.3)$ & $(3.6)$ & $(2.9)$ & $(2.7)$ & $(1.6)$ & $(2.9)$ & $(5.6)$ & $(4.9)$ & $(4.3)$ \\
Mild & 16 & 19.3 & 26.1 & 33.5 & 25.1 & 109.4 & 184.7 & 216.8 & 217.3 & 189.1 \\
diabetes & & $(4.5)$ & $(4.1)$ & $(5.2)$ & $(3.4)$ & $(5.6)$ & $(6.8)$ & $(11.1)$ & $(10.5)$ & $(9.2)$ \\
Moderate & 9 & 22.6 & 20.3 & 24.3 & 18.7 & 168.0 & 256.1 & 310.4 & 293.1 & 268.8 \\
diabetes & & $(4.9)$ & $(4.1)$ & $(4.4)$ & $(4.6)$ & $(6.1)$ & $(16.7)$ & $(19.1)$ & $(18.0)$ & $(19.1)$ \\
Severe & 11 & 10.0 & 16.9 & 15.6 & 17.9 & 231.0 & 310.7 & 389.1 & 374.5 & 346.5 \\
diabetes & & $(2.1)$ & $(3.8)$ & $(3.0)$ & $(3.4)$ & $(8.2)$ & $(21.2)$ & $(21.6)$ & $(21.9)$ & $(17.5)$ \\
& & & & & & & & &
\end{tabular}

Numbers in parentheses represent the standard errors. 
TABLE 4. Extractable insulin in plasma of diabetic patients with insulin antibody

\begin{tabular}{l|c|c|c|c|c}
\hline Patients & Sex & $\begin{array}{c}\text { Age } \\
\text { (year) }\end{array}$ & $\begin{array}{c}\text { Fasting blood } \\
\text { sugar }(\mathrm{mg} / \mathrm{l00 \textrm {ml } )}\end{array}$ & $\begin{array}{c}\text { Index of insulin } \\
\text { antibody } \%)\end{array}$ & $\begin{array}{c}\text { Insulin } \\
(\mu \mathrm{U} / \mathrm{ml})\end{array}$ \\
\hline K.S. & M & 30 & 147 & 21 & 32 \\
H.Y. & M & 28 & 123 & 21 & 14 \\
Y.K. & F & 57 & 198 & 22 & $145^{*}$ \\
S.A. & F & 27 & 139 & 33 & 10 \\
I.S. & F & 46 & 181 & 35 & 24 \\
M.Y. & M & 18 & 149 & 36 & $84^{*}$ \\
T.M. & M & 4 & 185 & 42 & $390^{*}$ \\
K.T. & M & 37 & 116 & 47 & $66^{*}$
\end{tabular}

* Insulin injection was not discontinued at least 24 hours prior to the examination.

insulin of plasma ranged from 10 to $32 \mu \mathrm{U}$ per $\mathrm{ml}$ in the diabetics whose insulin injection was discontinued 24 hours or more prior to venipuncture, whereas the value was elevated in the patients whose insulin injection was not discontinued.

\section{Discussion}

It has been reported that rat serum or human plasma might inhibit the second reaction of the two-antibody assay system for insulin and that it might interfere with the assay method. Morgan and Lazarow attributed this inhibition to complement, ${ }^{9}$ whereas cross reaction between human gamma-globulin and the second antibody was reported by Hales and Randle ${ }^{8}$ and Kuzuya and Samols. ${ }^{19}$ Although the cross reaction between human plasma and anti-guinea pig serum was observed by immuno-electrophoresis in our laboratory, ${ }^{20}$ untreated human plasma showed strong inhibition in the precipitation reaction. Furthermore, addition of EDTA to the incubation mixture reduced the inhibitory effect of human plasma upon the second antigen-antibody reaction. ${ }^{9}$ These results suggest that the inhibition in the second reaction is attributable mostly to the complementary action of human plasma and that it might be overcome by various ways. ${ }^{9-11,19}$

On the other hand, endogenous antibody to insulin is produced in almost all diabetics who have been treated with insulin. ${ }^{12,13}$ In the radioimmunoassay for insulin, the plasma concentration of insulin with endogenous insulin antibody might be measured erroneously. In order to eliminate the effect of endogenous insulin antibody upon the insulin assay, Grodsky and Forsham ${ }^{2}$ extracted the plasma of the patients with insulin resistent diabetes and Yalow and Berson ${ }^{21}$ separated plasma insulin from endogenous antibody on ultracentrifugation. A double incubation method was reported by Horiuchi ${ }^{22}$ and Nakagawa ${ }^{23}$ for the removal of endogenous antibody to insulin. According to them, a complex of anti-insulin guinea pig serum and plasma insulin was precipitated by anti-guinea pig gamma-glubolin. After the precipitate was incubated with labeled insulin for 120 hours, bound labeled insulin was precipitated by the addition of antiguinea pig gamma-globulin, and the $\mathrm{B} / \mathrm{F}$ ratio was calculated, 
Since anti-human globulin rabbit serum failed to remove the endogenous antibody to insulin, we attempted the extraction of plasma insulin. Several methods for the extraction of plasma insulin have been reported ${ }^{2,18,24}$ as the modifications of the method of isolation of pancreatic insulin, but for the removal of human globulin and endogenous insulin antibody, it was disadvantageous to apply to whole procedure in respective methods, because, when the whole procedure as employed for the extraction of the pancreatic insulin was applied to plasma insulin, the rate of recovery of circulating insulin in plasma was considerably reduced. Grodsky and Forsham ${ }^{2}$ reported that about $80 \%$ of added insulin-131I in plasma was extracted by their method, but a high recovery rate could not be obtained by their extraction method in our laboratory. Recently Ide and co-workers ${ }^{24}$ reported that salt ethanol method for the extraction of plasma insulin had several merits as compared with acid ethanol procedure. In their methods, $5 \mathrm{ml}$ of serum were used and the same procedures as used for the extraction of insulin from the pancreas were employed. However, in order to process many samples for insulin assay, a simple method with high recovery is required. In our case, $80 \%$ or more of human insulin or labeled insulin added to human plasma could be recovered by extraction with the relatively simple modified Scott's method as shown in Table 2. According to Ide and co-workers, ${ }^{24}$ small amounts of albumin and globulin fractions were found in the extract obtained by the acid ethanol method. However, when the same acid ethanol method was performed in our laboratory, neither albumin nor globulin was detected in the extract. ${ }^{20}$ In our experiment, the reconstituted solution of the extract obtained by the modification of Scott's method contains an albumin fraction but not a globulin fraction as judged by the electrophoresis, as shown in Fig. 1. Albumin fraction does not interfere with the results in the radioimmunoassay for insulin, whereas it does in the biological assay method for insulin. ${ }^{20}$ The reconstituted extract contains protein as little as $0.6 \mathrm{~g}$ per $100 \mathrm{ml}$ in the mean value and this might serve for the reduction in the minute amount of insulin adhering to the glassware.

It is evident from the result that insulin bound to antibody in human plasma can be extracted by the present method in a high recovery rate. This may be due to the fact that the complex of insulin and antibody is dissociated at low $\mathrm{pH}$. Therefore, enormously high insulin level may be measured in plasma of patients with insulin antibody, especially in the insulin-resistant patients as reported by Grodsky and Forsham, ${ }^{2}$ even if the insulin administration was discontinued several days before the blood sampling. ${ }^{20}$ However, as shown in Table 4, the fasting plasma insulin value as measured by the present extraction method was found to be 10 to $32 \mu \mathrm{U}$ per $\mathrm{ml}$ for the diabetic patients with endogenous insulin antibody, if exogenous insulin was withdrawn 48 hours or more before collecting the blood. High value of insulin in the extract from several patients with insulin antibody and to whom the insulin injection was not discontinued at least 24 hours prior to the examination (cf. Table 4) might be due to the dissociation of insulin from the complex during the extraction procedure and possibly to an injected insulin 
fraction still remaining in the circulating blood.

Another problem in the extraction of insulin is the possibility that circulating insulin in plasma might be modified or changed by the extraction. ${ }^{23}$ As far as immunoreactivity is concerned, this point has little significance, because human or beef insulin, which was used as a standard in the insulin assay was also the product prepared from the pancreas by the acid ethanol extraction.

The value of the fasting plasma insulin of 14 healthy subjects measured in our laboratory was 20.5 ( $\pm \mathrm{SE} 3.3$ ) $\mu \mathrm{U}$ per ml, whereas the fasting insulin measured by the single antibody system in untreated plasma ranged from 0 to $66 \mu \mathrm{U}$ per ml. ${ }^{25}$ If the recovery rate in the extraction is considered, there is no difference between the fasting insulin level reported by other authors ${ }^{25}$ and that measured in our laboratory. In this experiment a markedly decreased insulin response to glucose was observed in the severe untreated diabetic group, whose fasting blood sugar was above $200 \mathrm{mg}$ per $100 \mathrm{ml}$. The virtual absence of insulin response to glucose was reported by Yalow and Berson ${ }^{21}$ and Nakagawa ${ }^{23}$ in severe diabetics who had been injected with insulin and had its antibody. These results are consistent with the report of Seltzer, ${ }^{26}$ that circulating insulin-like activity measured by the rat diaphragm method was decreased in response to the glucose loading in severe diabetes.

There have been few reports ${ }^{2,21,23,27}$ concerning the concentration of plasma insulin in diabetic patients with insulin antibody. This is probably because of the interference in insulin assay by its antibody and difficulty in the withdrawal of insulin injection. However, the level of insulin in plasma of insulin-dependent patients with antibody to insulin can be estimated by applying the extraction of circulating insulin and the endocrine function of the pancreas of patients with severe diabetes might be clarified.

\section{Acknowledgment}

We wish to thank Dr. Y. Koga, Shimizu Pharmaceutical Co., Shimizu, Japan, for his advice with this project. Human insulin used in the experiment was donated by Mrs. Mary Root, Ph. D., Eli Lilly Co., Indianapolis, Ind., U.S.A.

\section{References}

1) Yalow, R.S. \& Berson, S.A. Immunoassay of endogenous plasma insulin in man. J. clin. Invest., 1960, 39, $1157-1175$.

2) Grodsky, G.M. \& Forsham, P.H. An immunochemical assay of total extractable insulin in man. J. clin. Invest., 1960, 39, 1070-1079.

3) Morgan, C.R. \& Lazarow, A. Immunoassay of insulin using a two-antibody system. Proc. Soc. exp. Biol. Med., 1962, 110, 29-32.

4) Meade, R.C. \& Klitgaard, H.M. A simplified method for immuno-assay of human serum insulin. J. nucl. Med., 1962, 3, 407-416.

5) Genuth, S., Frohman, L.A. \& Lebovitz, H.E. A radioimmunological assay method for insulin using insulin-125 I and gel filtration. J. clin. Endocr., 1965, 25, 1043-1049.

6) Herbert, V., Lau, K., Gottlieb, C.W. \& Bleicher, S.J. Coated charcoal immunoassay of insulin. J. clin. Endocr., 1965, 25, 1375-1384.

7) Morgan, C.R. \& Lazarow, A. Immunoassay of insulin: Two antibody system. 
Plasma insulin levels of normal, subdiabetic and diabetic rats. Diabetes, 1963, 12, 115-126.

8) Hales, C.N. \& Randle, P.J. Immunoassay of insulin with insulin-antibody precipitate. Biochem. J., 1963, 88, I37-146.

9) Morgan, C.R., Sorenson, R.L. \& Lazarow, A. Further studies of an inhibitor of the two antibody immunoassay system. Diabetes, 1964, 13, 579-584.

10) Soeldner, J.S. \& Slone, D. Critical variables in the radioimmunoassay of serum insulin using the double antibody technic. Diabetes, 1965, 14, 771-779.

II) Welborn, T.A. \& Fraser, T.R. The double antibody immunoassay of insulin. A standardized second antibody reaction that eliminates spurious results with human serum. Diabetologia, 1966, 1, 211-218.

12) Berson, S.A., Yalow, R.S., Bauman, A., Rothschild, M.A. \& Newerly, K. Insulin-I131 metabolism in human subjects: Demonstration of insulin binding globulin in the circulation of insulin treated subjects. J. clin. Invest., 1956, 35, 170-190.

13) Yamagata, S., Ohneda, A. \& Kubota, N. Studies on insulin antibody. J. Japan Diabetic Society (Jap.), 1965, 8, 186.

14) Ishida, N., Hinuma, Y. \& Ohta, R. Practice in fluorescent antibody method. Rinshobyori (Jap.), 1961, 9, 470-476.

15) Scott, D.A. \& Fisher, A.M. The insulin and the zine content of normal and diabetic pancreas. J. clin. Invest., 1938, 17, 725-728.

16) Fujita, A. \& Iwatake, D. Bestimmung des echten Blutzuckers ohne Hefe. Biochem. $Z ., 1931,242,43-60$.

17) Hagedorn, H.C. \& Jensen, B.N. Zur Mikrobestimmung des Blutzuckers mittels Ferricyanid. Biochem. Z., 1923, 135, 46-58.

18) Mineshita, T. Measurement of minute insulin. J. Japan diabetic Soc. (Jap.), I959, 2, 12-15.

19) Kuzuya, T. \& Samols, E. The plasma insulin 'inhibitor' and immunoprecipitation assay. Metabolism, 1964, 13, 493-495.

20) Ohneda, A. Plasma insulin in normal and pathological states. J. Japan diabetic Society (Jap.), 1966, 9, 353 -357.

21) Yalow, R.S. \& Berson, S.A. Immunoassay of plasma insulin in man. Diabetes, $1961,10,339-344$.

22) Horiuchi, Y. Radioimmunoassay of insulin. Folia endocr. jap. (Jap.), 1966, 42, $467-474$.

23) Nakagawa, S. Insulin antibody in blood. J. Japan diabetic Soc. (Jap.), 1966, 9, 357-361.

24) Ide, T., Kuzuya, T. Kajinuma, H., Kanazawa, Y. \& Kosaka, K. Insulin-like activity by fat pad assay and immunoreactive insulin. I. Their correlation in native serum, acid-ethanol extract and salt-ethanol extract. Diabetes, 1969, 18, 65-74.

25) Yalow, R.S. \& Berson, S.A. Plasma insulin in man. Amer. J. Med., 1960, 29, 1-8.

26) Seltzer, H.S. \& Smith, W.L. Plasma insulin activity after glucose. An index of insulogenic reserve in normal and diabetic man. Diabetes, 1959, 8, 417-424.

27) Karam, J.H., Levin, S.R., Lecharny, B., Grodsky, G.M. \& Forsham, P.H. Circulating insulin levels in insulin-treated diabetes. Diabetes, 1969, 18, 361-362. 